\title{
Seismic Attribute-Aided Characterization of Margin Backstepping and Advance along Isolated Carbonate Sequences, Sirt Basin, Libya
}

\author{
Muneer A. Abdalla \\ Department of Geography, Faculty of Science, Omar Al-Mukhtar University, Al Bayda, Libya
}

Received: 18 May 2021/ Accepted:10 November 2021

Doi: https://doi.org/10.54172/mjsc.v36i4.590

\begin{abstract}
Isolated carbonate platforms are common and contain significant hydrocarbon accumulations, particularly in the tectonically complex Sirt Basin in Libya. This study investigates the margin cyclicity of two carbonate stratigraphic sequences developed on an isolated carbonate platform in the NW Sirt Basin using 3-D post-stack seismic volume and wireline $\log$ data. The two sequences (sequences 4 and 5) are bounded by unconformity surfaces from the base and top. Seismic attributes show that each sequence displays a cycle of margin backstepping followed by margin advance for several hundred meters. This study concludes that the margin backstepping and advance are mainly influenced by sea-level changes. A rapid sea-level rise caused the backstepping, whereas slow sea-level rise caused the margin advance.
\end{abstract}

Keywords: Cyclicity, Sea-level changes, Isolated carbonate platform, Sirt Basin, Libya

\section{INTRODUCTION}

The study area is situated in the NW Sirt Basin, the largest sedimentary basin in Libya. (Fig. 1). The basin formed due to large-scale extension and associated subsidence and faulting during the Early Cretaceous to Early Eocene (Guiraud \& Bosworth, 1997; Hallett, 2002). This crustal extension and subsidence led to the formation of NW-SE trending horsts and grabens shown in Figure 2. The thickness of the sedimentary strata of the basin varies from $\sim 7 \mathrm{~km}$ in the eastern part of the basin to $\sim 1 \mathrm{~km}$ in the west (Fig. 2; Roohi, 1996). The Sirt Basin is ranked 13th among the world's largest hydrocarbon basins, with estimated reserves of 43.1 billion barrels of oil (Ahlbrandt, 2001).

The studied area is located in the west Mabruk Oilfield of the northwestern part of the Sirt Ba$\sin$ (Fig. 1). The area contains a NW-SE oriented isolated carbonate platform that started to form during the early Paleocene and demised during the early Eocene due to a sea-level drop that led to a subaerial exposure (Abdalla \& Yang, 2021). The isolated platform occupies an area of approximately $113 \mathrm{~km}^{2}$ and is characterized by a reef buildup at the margins (Fig. 3 ). The platform was divided into five stratigraphic sequences based on reflection termination patterns. Some of the delineated sequences (e.g., Sequences 4 and 5) were subdivided into systems tracts on the basis of wireline log analysis (Abdalla \& Yang, 2021).

However, the marginal area of Sequences 4 and 5 do not show a clear cyclicity on vertical seismic sections, perhaps due to the small range of margin migration or the limitation of the 3-D seismic data. Therefore, this study utilizes seismic attributes in order to characterize the cyclicity of the platform margins and emphasis the role of sea-level changes on the development of isolated carbonate platforms.

*Corresponding Author: Muneer Abdalla Muneer.abdalla@omu.edu.ly, Department of Geography, Faculty of Science, Omar Al-Mukhtar University, Al Bayda, Libya. 


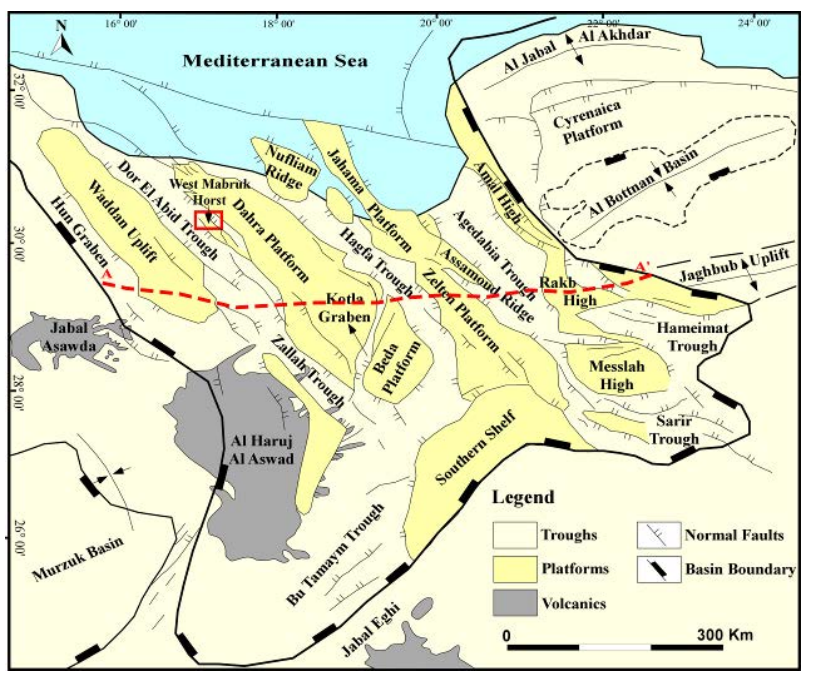

Figure (1). Structural map of the Sirt Basin (modified after Abadi et al., 2008; Mouzughi \& Taleb, 1981). Most normal faults have a NW-SE orientation. Study area is outlined by the red box.

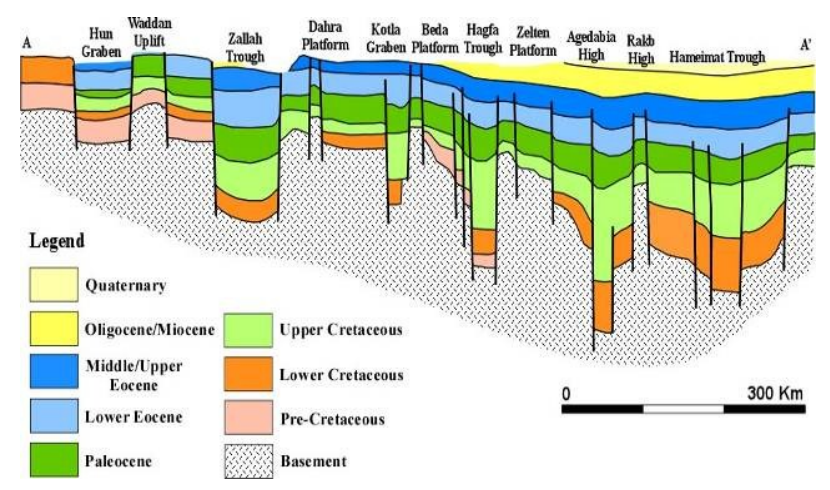

Figure (2). East-west cross-section showing the major structural features across the Sirt Basin (modified after Roohi, 1996). Location of the cross section is outlined by the dashed line in Figure 1.

\section{MATERIALS AND METHODS}

3-D post-stack seismic volume and wireline logs from two wells are used to characterize the cyclicity of Sequences 4 and 5. The seismic survey covers an area of around $113 \mathrm{~km}^{2}$, and has $25 \times 25 \mathrm{~m}^{2}$ grid spacing, 1000 inlines, 500 crosslines, and a maximum two-way travel time of 4 seconds. The seismic data has an SEG normal polarity, where the increase in acoustic impedance is illustrated as positive amplitude, which is seen on seismic sections as black reflection. The frequency ranges from $7-$ $55 \mathrm{~Hz}$ with a dominant frequency of $22-35 \mathrm{~Hz}$. The types of wireline logs available for this study include gamma ray (GR), acoustic (AC), spontaneous potential (SP), caliper (CAL), Resistivity, density (RHOB), and neutron (NPHI) logs.

Seismic attributes utilized in this study include: 1) whitening method which was used to enhance the seismic data resolution. This method utilizes the information in low frequencies to correct and predict the high frequencies without adding any noise to the original seismic dataset (Barnes, 2016) median filter attribute which was applied to the original post-stack 3$\mathrm{D}$ seismic data in order to remove the random noise (Barnes, 2016). The method was utilized before the extraction of the interpretation attribute so as to improve the resolution of the 3D seismic data (Figs. 3 and 4); and 3) root mean square (RMS) attribute, which is similar to a smoother version of reflection strength. It was applied here to show and measure the distance of platform margin cyclicity (Figs. 6 and 7).

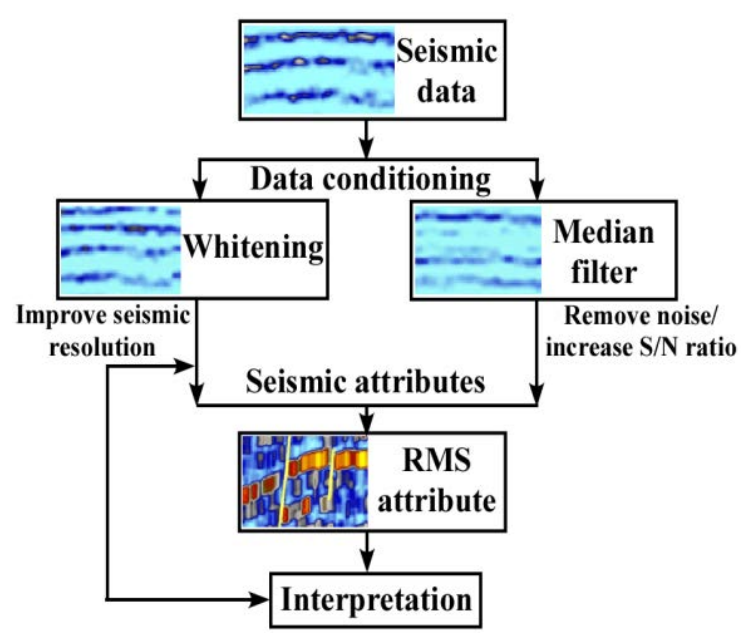

Figure (3). Workflow used in this study to create the seismic attribute.

\section{RESULTS AND DISSCUSION}

Sequence Stratigraphy: Five seismic stratigraphic sequences (S) were delineated within the isolated platform on the basis of reflection termination patterns, seismic reflections geometries, and stacking patterns (Fig. 5A; Abdalla 
\& Yang, 2021). Those sequences are equivalent to the depositional sequences defined by (Mitchum Jr, 1977). They exist across the whole study area and cover an area of at least $113 \mathrm{~km}^{2}$. The sequence boundaries (SB) sepa- rating the seismic stratigraphic sequences are delineated by truncational or toplap terminations below, and onlap above. Sequences 4 and 5 are described in detail below.
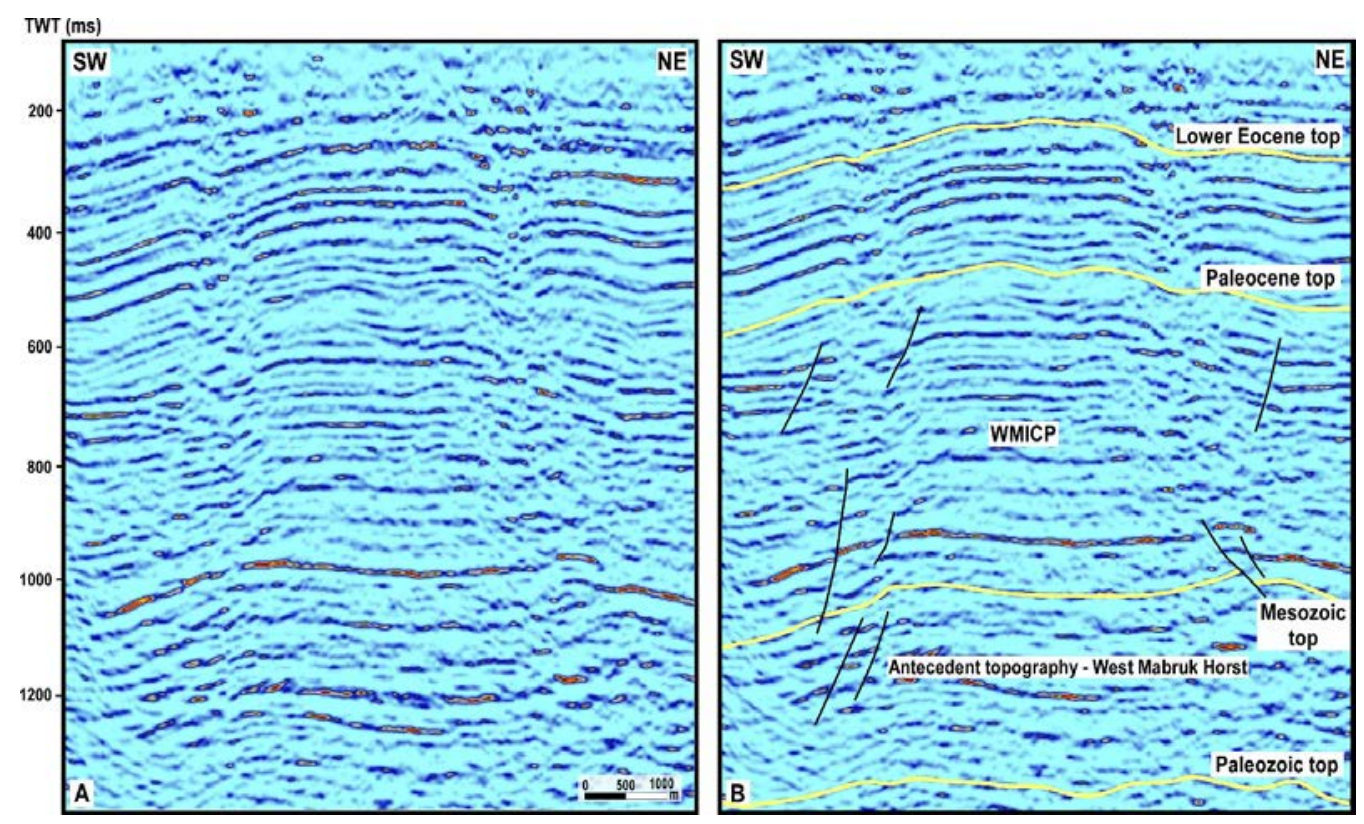

Figure. (4. A). Original seismic inline 4600. (4.B) Same inline after applying the whitening and median filter attributes. Note that seismic data quality is improved after applying the median filter and whitening compared to original seismic data

Sequence 4: Sequence 4 unconformably overlies sequence 3 . It is bounded by SB4 at the base and SB5 at the top. The platform margin of S4 displays a rapid vertical growth of reef buildup and retreated margins. This sequence seismically shows medium amplitude, subparallel to parallel, continuous reflections at the platform interior; chaotic reflections at the platform edges; and sigmoidal, continuous reflections at the slopes (Fig. 5A). Occasionally at the platform top, the subparallel to parallel facies changes laterally to mound-shaped facies. Only the upper portion of Sequence 4 is penetrated by wells (Fig. 5B). This portion can be divided into a low-order transgressive and regressive sequence that comprises four highorder transgressive and regressive cycle sets (Fig. 5B). The thickness of the transgressive interval is $24 \mathrm{~m}$, and that of the regressive interval is $115 \mathrm{~m}$. The transgressive interval mainly consists of shale, mudstones, and minor wackestones. Whereas the regressive interval contains mudstones and wackestones with some packstones and grainstones (Fig. 5B). The margins are characterized by cycles of backstepping followed by progradation. Root mean square (RMS) amplitude time slices along S4 at 780, 750, and $720 \mathrm{~ms}$. TWT shows margin backstepping followed by margin advance. Time slices show that both margins backstepped towards the platform interior (Fig. $6 \mathrm{~B})$. The platform margins are seen on the time slices as S-N linear, high amplitude anomalies (Fig. 6). The reef retreated around $700 \mathrm{~m}$ on both margins (Fig. 6B), and then prograded towards the basin for around $400 \mathrm{~m}$ (Fig. 6C).

Sequence 5: Sequence 5 is the shallowest and bounded by SB5 at the base and SB6 at the top. The seismic characteristics of S5 are similar to 
S4. The only notable difference is that the S5 seismic reflections have a higher amplitude compared to S4. S5 displays a decrease of the platform top area and retreated margins compared to S4 (Fig. 5A). In well data, the platform-top facies of this sequence is divided into low-order transgressive and regressive intervals that comprise three high-order transgressive and regressive cycle sets (Fig. 5B). The thickness of the transgressive portion is $69 \mathrm{~m}$, whereas the regressive portion has a thickness

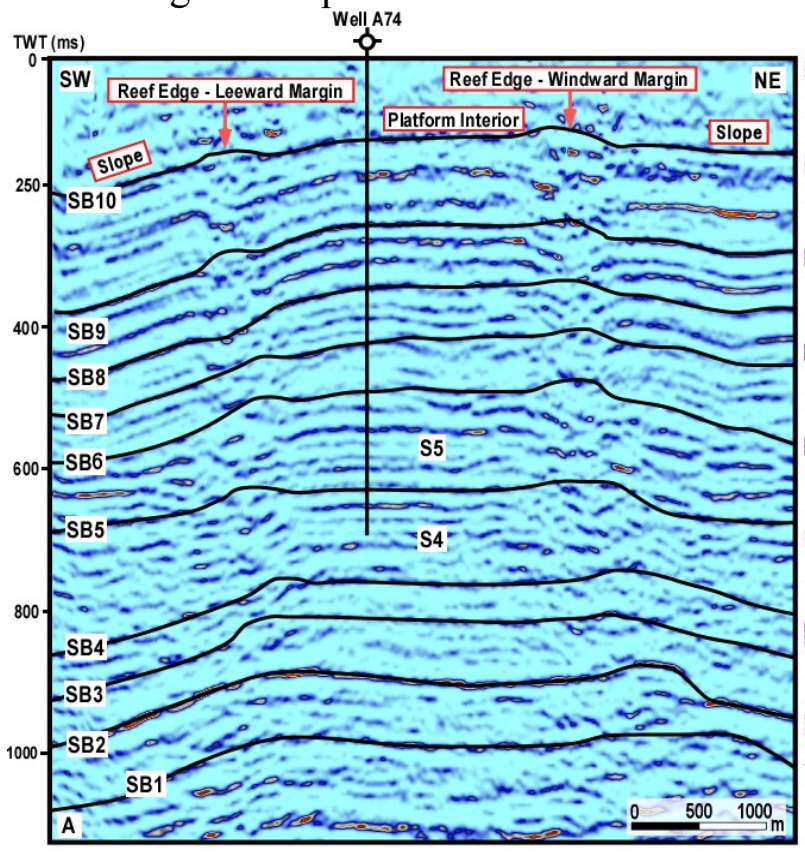

of $163 \mathrm{~m}$. The transgressive portions are composed of shale and mudstones and the regressive portions predominantly comprise mudstones and wackestones (Fig. 5B).

Root mean square (RMS) time slices along S5 at 680,650 , and $610 \mathrm{~ms}$. TWT shows margin backstepping followed by margin advance (Fig. 7). The margin retreated around $550 \mathrm{~m}$ on both margins (Fig. 7B), and then prograded basinward for around $350 \mathrm{~m}$ (Fig. 7C).

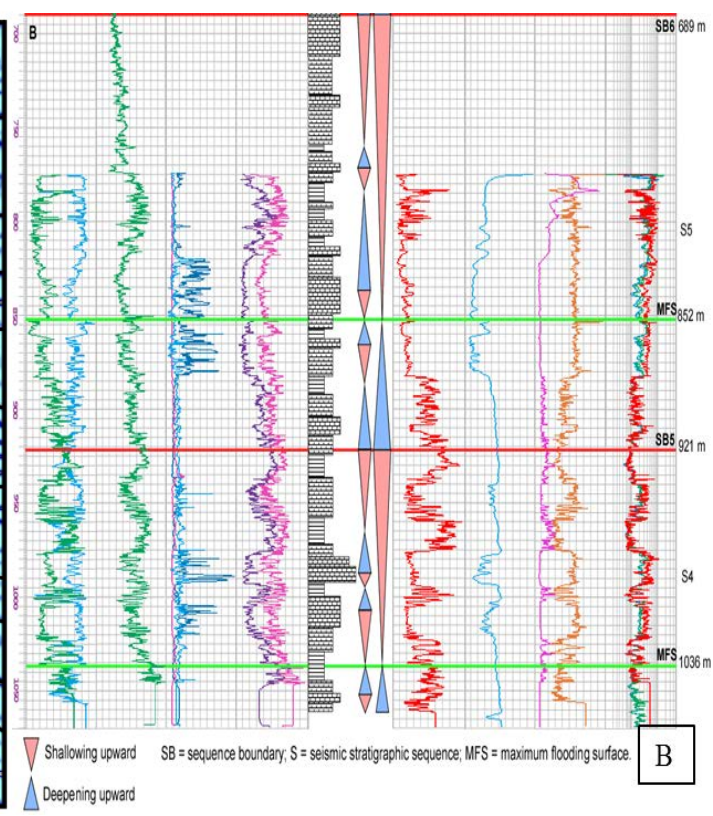

Figure (5. A). Interpreted SW-NE seismic section of the platform showing all sequence and their boundaries. (5.B) Interpretation of lithologies, stratigraphic surfaces, and sequences of well A74

\section{Sea-level Control on Margin Backstepping and Advance}

The term backstepping or margin retreat is described as the landward migration of reef or margin complexes. It implies the demise of a reef complex at one site and its regrowth at another site towards the land (Blanchon, 2011). Backstepping has been widely reported in many studies throughout geological history, where it is usually interpreted due to a rapid increase in sea level (Becker et al., 1993; Schlager, 2005). On the contrary, the reef or 

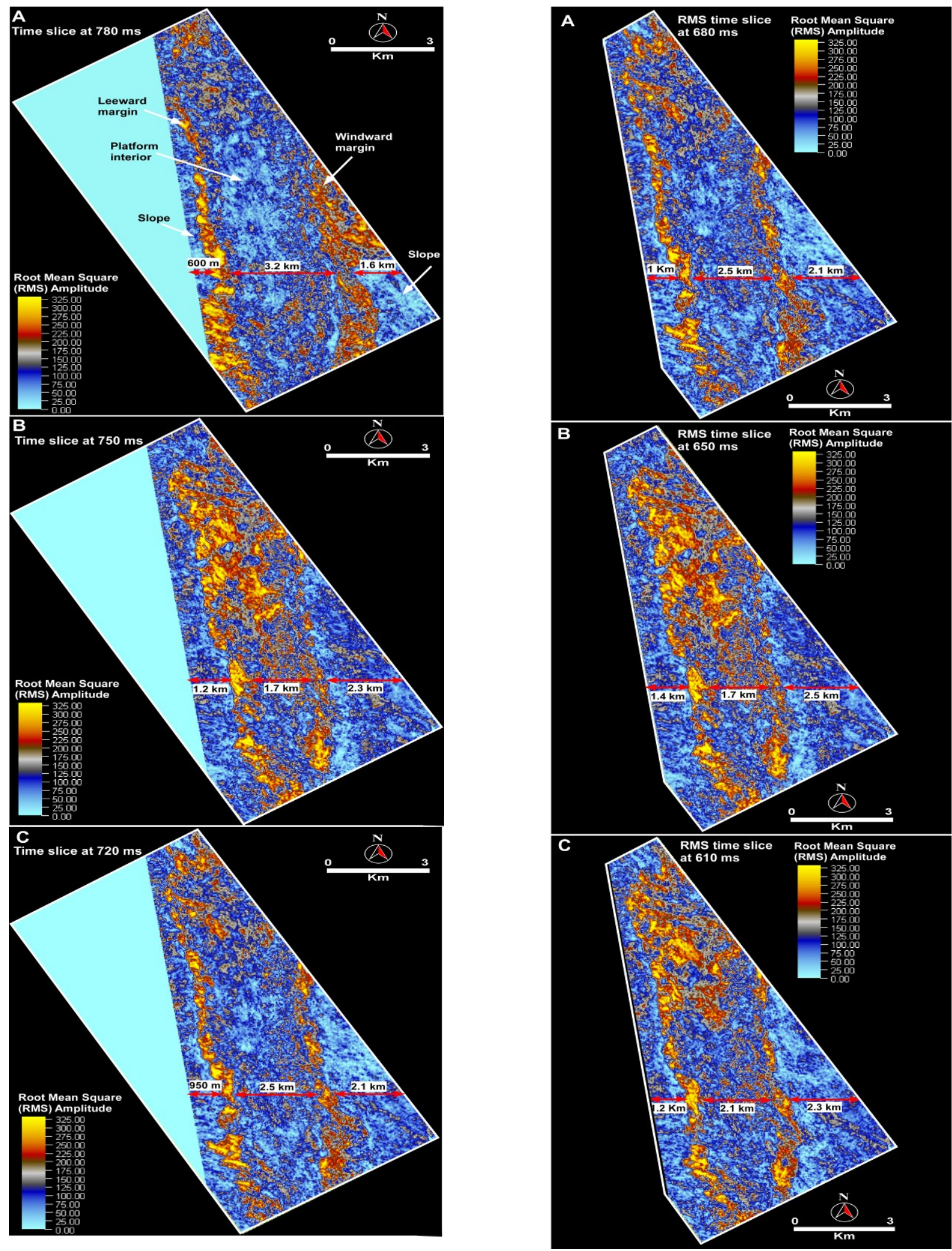

Figure (6). Root mean square (RMS) amplitude time slices (6.A, 6.B, and 6.C) along Sequence 4 showing the margin backstepping and advance. The margins are the S-N linear high-amplitude anomalies that migrate Figure (7). Root mean square (RMS) amplitude time slices (7. A, 7. B, and 7. C) along Sequence 4 showing the margin backstepping and advance. towards the platform interior.

(C) 2021 Muneer Abdalla. This open access article is distributed under a Creative Commons Attribution (CC-BY) 4.0 license. ISSN: online 2617-2186 print 2617-2178 
margin advance or progradation occurs as a result of sea-level lowstands or highstands when the rate of creation of sediment supply is higher than the accommodation space (Schlager, 2005). In this study, the margin retreat may have been caused by a rapid sealevel rise, and the margin progradation perhaps occurred as a result of sea-level highstands. This is supported by the transgressive and regressive cycle sets delineated on wireline logs, which coincide with the margin backstepping and advance which are indicated by the root mean square (RMS) amplitude time slices.

\section{CONCLUSION}

This study utilizes a 3-D seismic volume and wireline log data to characterize the margin cyclicity of carbonate stratigraphic sequences along an isolated carbonate platform in the NW Sirt Basin in Libya. Two stratigraphic sequences are characterized (Sequences 4 and 5) in order to reveal the control of sea-level fluctuations on the migration of platform margin. Both sequences show margin backstepping followed by margin progradation for several hundred meters as shown by seismic attributes. This study concludes that the margin backstepping occurred as a result of a rapid sea-level rise, whereas the margin progradation occurred due to sea-level highstands when sediment supply outpaces accommodation space.

\section{ACKNOWLEDGEMENTS}

We thank the Libyan National Oil Corporation (NOC) for providing the data used in this study.

\section{REFERENCES}

Abadi, A. M., Van Wees, J.-D., Van Dijk, P. M., \& Cloetingh, S. A. (2008). Tectonics and subsidence evolution of the Sirt Basin, Libya. AAPG bulletin, 92(8), 993-1027.

Abdalla, M., \& Yang, W. (2021). Progradation of a middle Eocene carbonate slope system, Assamoud Field, Sirte Basin, north central Libya-Implications on the dynamics of lateral growth of isolated carbonate platforms. Marine and Petroleum Geology, 129, 105119 .

Ahlbrandt, T. S. (2001). The sirte basin province of Libya: sirte-zelten total petroleum system. US Department of the Interior, US Geological Survey .

Barnes, A. E. (2016). Handbook of poststack seismic attributes. Society of Exploration Geophysicists .

Becker, R., House, M., \& Kirchgasser, W. (1993). Devonian goniatite biostratigraphy and timing of facies movements in the Frasnian of the Canning Basin, Western Australia. 293-321. High resolution biostratigraphy. Geological Society, London, Special Publication, 70, 357 .

Blanchon, P. (2011). Back-stepping. Encyclopedia of Modern Coral Reefs: Structure, form and process: New York, Springer-Verlag, 77-84 .

Guiraud, R., \& Bosworth, W. (1997). Senonian basin inversion and rejuvenation of rifting in Africa and Arabia: synthesis and implications to plate-scale tectonics. Tectonophysics, 282(1-4), 3982 .

Hallett, D. (2002). Petroleum geology of Libya: BV Elsevier. Amsterdam, The Netherlands .

Mitchum Jr, R. (1977). Seismic stratigraphy and global changes of sea level: Part 11. Glossary of terms used in seismic stratigraphy: Section .2 Application of seismic reflection configuration to stratigraphic interpretation . 
Mouzughi, A., \& Taleb, T. (1981). Tectonic Elements of Libya (1: 2,000,000). National Oil Corporation of Libya .

Roohi, M. (1996). A geological view of sourcereservoir relationships in the western Sirt Basin. Geology of the Sirt Basin: Amsterdam, Elsevier, 2, 323-336.

Schlager, W. (2005). Carbonate sedimentology and sequence stratigraphy. SEPM (Socity Sedimentary for Geology) USA. 


\title{
استخدام السمات السيزمية لتحديد تقدم وتراجع حواف الأرصفة الكريونية المنعزلة في حوض سرت - ليبيا
}

\author{
منير علي اللطيف عبد الله \\ قسم الجيولوجيا، كلية العلوم، جامعة عمر المختار، البيضاء - ليييا

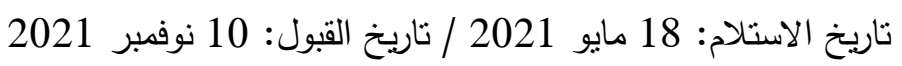 \\ https://doi.org/10.54172/mjsc.v36i4.590:Doi
}

المستخلص: تعتبر الأرصفة الكربونية المنعزلة من أهم التراكيب الرسوبية الحاوية على تجمعات هيدروكربونية كما توجد بكثرة في

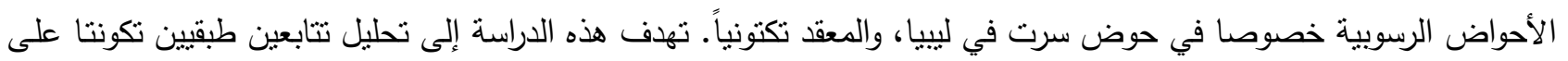

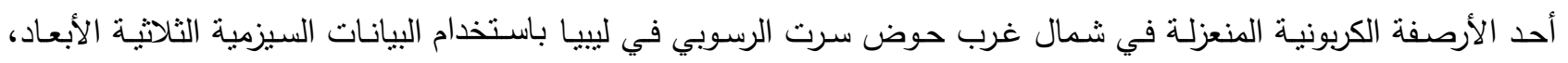

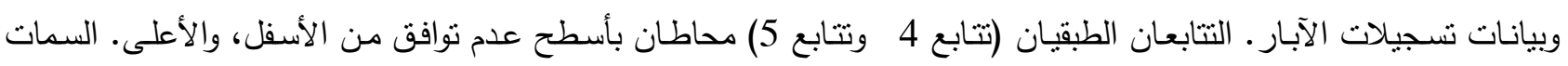

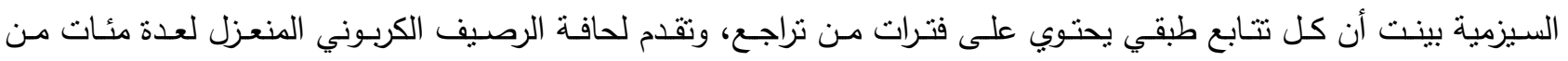

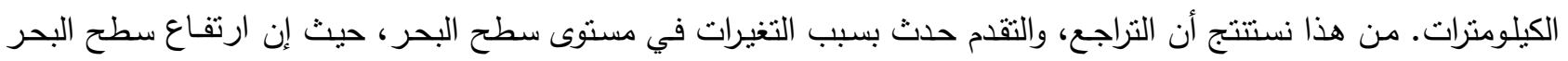
الكفاجئ يسبب تراجعا للحافة الكربونية المنعزلة بينما ارتفاع سطح البحر البطيء، أو الثابت يسبب نقدماً للحافة الكربونية المنعزلة.

الكلمات المفتاحية: تقدم وتراجع، التغيرات في مستوى سطح البحر ، الرصيف الكربوني المنعزل، حوض سرت، ليبيا. 